\title{
The origin and composition of carbonatite-derived carbonate- bearing fluorapatite deposits
}

Sam Broom-Fendley ${ }^{1 *}$, Pete R. Siegfried ${ }^{1,2}$, Frances

Wall ${ }^{1}$, Mary O’Neill ${ }^{1}$, Richard A. Brooker ${ }^{3}$, Emily K.

Fallon $^{3}$, Jonathan R. Pickles ${ }^{1}$, and David A. Banks ${ }^{4}$

${ }^{1}$ Camborne School of Mines, University of Exeter, TR10 9FE, U.K. **s.l.broom-fendley@ex.ac.uk

${ }^{2}$ GeoAfrica Prospecting Services CC, PO Box 24218, Namibia

${ }^{3}$ School of Earth Sciences, University of Bristol, BS8 1RJ, U.K.

${ }^{4}$ School of Earth and Environment, University of Leeds, LS2 9JT, U.K.

Carbonate-bearing fluorapatite rocks occur at over 30 globally-distributed carbonatite complexes and represent a substantial potential supply of phosphorus for the fertilizer industry. However, the process(es) involved in forming carbonate-bearing fluorapatite at some carbonatites remain equivocal, with both hydrothermal and weathering mechanisms inferred.

In this contribution we compare the paragenesis and trace element contents of carbonate-bearing fluorapatite rocks from the Kovdor, Sokli, Bukusu, Catalão I, and Glenover carbonatites in order to further understand their origin, as well as to comment upon the concentration of elements that may be deleterious to fertilizer production. The paragenesis of apatite from each deposit is broadly equivalent, comprising residual magmatic grains overgrown by several different stages of carbonate-bearing fluorapatite. The first forms epitactic overgrowths on residual magmatic grains, followed by the formation of massive apatite which, in turn, is crosscut by late euhedral and colloform apatite generations.

Compositionally, the paragenetic sequence corresponds to a substantial decrease in the concentration of rare earth elements (REE), Sr, Na and Th, with an increase in $\mathrm{U}$ and $\mathrm{Cd}$. The carbonate-bearing fluorapatite exhibits a negative $\mathrm{Ce}$ anomaly, attributed to oxic conditions in a surficial environment and, in combination with the textural and compositional commonality, supports a weathering origin for these rocks. Carbonate-bearing fluorapatite has Th contents which are several orders of magnitude lower than magmatic apatite grains, potentially making such apatite a more environmentally attractive feedstock for the fertilizer industry. Uranium and cadmium contents are higher than magmatic carbonatite apatite, but are much lower than most marine phosphorites. 